\title{
Halogens in serpentinised-troctolites (Atlantis Massif): implications for the role of serpentinization in volatile subduction budgets
}

\author{
DR. MARK A KENDRICK ${ }^{1}$, MARGUERITE GODARD ${ }^{2}$ \\ AND MICHAEL A.W. MARKS ${ }^{3}$ \\ ${ }^{1}$ University of Queensland \\ ${ }^{2}$ Géosciences Montpellier, CNRS, U. Montpellier \\ ${ }^{3}$ Universitaet Tuebingen \\ Presenting Author: m.kendrick@uq.edu.au
}

The Atlantis Massif is an example of an oceanic core complex on the slow spreading Mid-Atlantic Ridge. The lithologies recovered from IODP Hole 1309D are dominated by gabbros and troctolites ( $>45$ vol. \% olivine) considered representative of the primitive lithologies expected in lower oceanic crust elsewhere. Previous work has shown that the troctolites are variably serpentinised and formed reactive, permeable fluid pathways in the lower crust.

Samples of serpentinised-troctolite $(\mathrm{n}=11)$ from Hole 1309D mostly have 20-40 ppm F, 200-2000 ppm Cl, 0.3-5 ppm Br, 2-10 ppb I. The combined data define a mixing trend in $\mathrm{Br} / \mathrm{Cl}-\mathrm{I} / \mathrm{Cl}$ space between end-members representing seawater and pristine crust (similar to MORB). In contrast, most gabbroic samples ( $\mathrm{n}=$ 11) have a similar range of $F$ concentrations but much lower concentrations of $20-200 \mathrm{ppm} \mathrm{Cl}$ together with variable $\mathrm{Br} / \mathrm{Cl}$ and $\mathrm{I} / \mathrm{Cl}$ ratios intermediate of pristine crust and amphibole, which preferentially excludes $\mathrm{Br}$ and I relative to $\mathrm{Cl}$. The range of $\mathrm{Br} / \mathrm{Cl}$ and $\mathrm{I} / \mathrm{Cl}$ in the serpentinised-troctolites confirms that serpentine-minerals can preserve seawater-like $\mathrm{Br} / \mathrm{Cl}$ and $\mathrm{I} / \mathrm{Cl}$ ratios. In contrast, forearc- and ophiolitic-serpentinites commonly have very high $\mathrm{Br} / \mathrm{Cl}$ and $\mathrm{I} / \mathrm{Cl}$ ratios overlapping sediment pore waters.

Arc lavas have variable $\mathrm{I} / \mathrm{Cl}$ and $\mathrm{Br} / \mathrm{Cl}$ ratios overlapping the range of serpentinised-troctolites and significantly lower than typical of forearc-serpentinites ${ }^{1}$. The new data are therefore consistent with seafloor- and/or slab-bend-serpentinites (and not forearc-serpentinites) as major sources of $\mathrm{Cl}$ in subduction zones. Subduction of serpentinites formed from seawater (with low $\mathrm{I} / \mathrm{Cl}$ ratios) could also explain a suggested decrease in mantle $\mathrm{I} / \mathrm{Cl}$ over Earth history ${ }^{1}$. The high concentration of $\mathrm{Cl}$ in serpentinised-troctolites and the expected presence of troctolites in lower oceanic crust elsewhere imply that serpentinisation of lower crustal lithologies, as well as the lithospheric mantle, should be included in volatile subduction budgets. Including serpentinised-troctolites from the lower crust in subduction budgets helps explain the presence of seawater-derived volatiles $\left(\mathrm{H}_{2} \mathrm{O}\right.$, halogens, noble gases) in the Earth's mantle.

1 - Kendrick, Danyushevsky, Falloon, Woodhead, Arculus, Ireland, 2020. SW Pacific arc and backarc lavas and the role of slab-bend serpentinites in the global halogen cycle. EPSL 530, 115921. 